\title{
Cooperative effect of gefitinib and fumitremorgin $c$ on cell growth and chemosensitivity in estrogen receptor $\alpha$ negative fulvestrant-resistant MCF-7 cells
}

\author{
HONG LIU $^{1}$, DONG CHENG $^{1 *}$, ALYSSA K. WEICHEL $^{1 *}$, CLODIA OSIPO $^{1}$, LAURA K. WING $^{1}$, \\ BIN CHEN $^{1}$, TERESA E. LOUIS ${ }^{1}$ and V. CRAIG JORDAN ${ }^{2}$
}

\author{
${ }^{1}$ Robert H. Lurie Comprehensive Cancer Center, Northwestern University, Feinberg School of Medicine, \\ 303 E. Chicago Avenue, Chicago, IL 60611; ${ }^{2}$ Fox Chase Cancer Center, 333 Cottman Avenue, Philadelphia, PA 19111, USA
}

Received March 16, 2006; Accepted April 18, 2006

\begin{abstract}
The selective ER downregulator, fulvestrant, is currently approved as a second line endocrine therapy after onset of resistance to prior antiestrogen therapy in postmenopausal breast cancer patients. Resistance to antihormonal therapies is common and, therefore, we anticipate that fulvestrant-resistance will occur as well. The current study was undertaken to investigate the underlying molecular changes after fulvestrant-resistance and find new therapeutic targets and agents for fulvestrant-resistant breast cancer cells. We developed a unique fulvestrant-resistant cell line (MCF-7/F), derived from MCF-7 estrogen receptor $\alpha(E R \alpha)$ positive human breast cancer cells, by culturing them in $1 \mu \mathrm{M}$ fulvestrant containing medium for $\sim 18$ months. MCF-7/F cells became irreversibly ER $\alpha$ negative as withdrawal of fulvestrant did not alter the ER $\alpha$-negative phenotype, determined by real-time PCR, Western blot analysis, and ERE-luciferase transfection assays. MCF-7/F cells grew in a hormoneindependent manner. Interestingly, MCF-7/F cells overexpressed both epidermal growth factor receptor (EGFR) and breast cancer resistant protein (BCRP). Gefitinib, a specific EGFR tyrosine kinase inhibitor, preferentially inhibited the growth of MCF-7/F cells relative to MCF-7 cells by inhibiting both $\mathrm{MAPK}^{44 / 42}$ and Akt phosphorylation. MCF-7/F cells became less sensitive to chemotherapeutic agents such as mitoxantrone. Moreover, fumitremorgin $\mathrm{C}$, a specific BCRP inhibitor, significantly increased the efficacy of mitoxantrone in MCF-7/F cells. Gefitinib increased the inhibitory effect of mitoxantrone on cell growth. Similarly, fumitremorgin C
\end{abstract}

Correspondence to: Dr V. Craig Jordan, Fox Chase Cancer Center, 333 Cottman Avenue, Philadelphia, PA 19111-2497, USA

E-mail: v.craig.jordan@fccc.edu

${ }^{*}$ Contributed equally

Key words: chemosensitivity, EGFR, breast cancer resistant protein, fulvestrant-resistance, breast cancer increased the inhibitory effect of gefitinib on cell growth, suggesting that there is a bidirectional crosstalk between EGFR and BCRP. More importantly, these results provide a molecular basis for using gefitinib, BCRP inhibitors, and chemotherapeutic agents as combination therapy approaches in fulvestrant-resistant breast cancer.

\section{Introduction}

Approximately two-thirds of breast cancer is estrogen receptor $\alpha(\mathrm{ER} \alpha)$ and/or progesterone receptor (PgR) positive. In ER $\alpha$ positive breast cancer, estrogens stimulate tumor growth by activating ER $\alpha$ transcription activity. Targeting the ER $\alpha$ with antiestrogen therapy has resulted in substantial advances in the treatment of breast cancer (1). Tamoxifen, a non-steroidal antiestrogen, has been used successfully for the treatment of all stages of ER $\alpha$ positive breast cancer (1), resulting in increased disease-free and overall survival (2). However, tamoxifen is a partial ER $\alpha$ agonist and as a result, has undesirable side-effects such as an increase in the incidence of endometrial cancer. In addition, most patients that initially respond to tamoxifen will eventually develop resistance during therapy. As a result of this knowledge, second line endocrine therapies blocking the ER $\alpha$ pathway via different mechanisms have now been established to inhibit the growth of breast tumors after tamoxifen failure. One of the approaches being advanced in the clinic is the use of the pure steroidal antiestrogen, fulvestrant (Faslodex $^{\circledR}$, ICI 182,780) $(3,4)$, This compound has a high binding affinity for ER $\alpha$, blocks ER $\alpha$ dimerization and DNA binding, and more intriguingly, targets ER $\alpha$ for degradation $(5,6)$. As a result of this specific action on ER $\alpha$, fulvestrant abolishes ER $\alpha$-mediated gene expression and exhibits no known ER $\alpha$ agonist activity (7). In two randomized, controlled clinical trials $(3,4)$ fulvestrant is as effective as anastrozole (Arimidex ${ }^{\circledR}$ ), an aromatase inhibitor, for advanced breast cancer in postmenopausal women with disease which failed previous endocrine therapy. Fulvestrant is now approved in the United States as a second line endocrine therapy for the treatment of breast cancer that has progressed on prior antiestrogen therapy in postmenopausal women and provides clinical benefit of longer disease control in patients with 
breast cancer resistant to tamoxifen. Although fulvestrant provides benefits with reduced side effects in tamoxifenresistant disease, drug resistance to fulvestrant will eventually occur. Thus, new therapeutic targets must be identified to further control the growth of fulvestrant-resistant breast tumors.

To understand the mechanism of fulvestrant-resistance and explore potentially new therapeutic targets, several fulvestrant-resistant breast cancer cell models have been reported (8-11). Most of these resistant cells remain ER $\alpha$ positive (8-10) and are still responsive to estrogen in terms of expression of certain ER $\alpha$ regulated genes such as $\mathrm{pS} 2(9,10)$, cathepsin D (9), or PgR (8), or estrogen-stimulated growth in vitro $(10)$ or in vivo $(8,9)$. T47D-r, ZR-75-r and MCF-7-r are $\mathrm{ER} \alpha / \operatorname{PgR}$ negative (11). However, these three reportedly resistant cell models were not tested for their phenotype stability by withdrawal of fulvestrant from culture medium. In the present study, we established unique fulvestrant-resistant human breast cancer cells $(\mathrm{MCF}-7 / \mathrm{F})$ that irreversibly lost ER $\alpha$ expression, overexpressed EGFR and breast cancer resistance protein (BCRP), and were less sensitive to chemotherapeutic agents such as mitoxantrone. Using this antihormone resistant cell model, we examined whether gefitinib and fumitremorgin C (FTC), a specific BCRP inhibitor (12), could be used as targeted combinations to improve chemosensitivity to cytotoxic drugs.

\section{Materials and methods}

Cell culture and materials. The MCF-7 cells used in this study (13) were cloned from MCF-7 ER $\alpha$-positive human breast cancer cells originally obtained from Dr Dean Edwards, University of Texas San Antonio, TX (1985). MCF-7/F cells were derived from MCF-7 cells by originally growing the cells for more than 12 months in the presence of $1 \mu \mathrm{M}$ fulvestrant (AstraZeneca Pharmaceuticals, Macclesfield, UK) in estrogenfree medium (phenol red-free minimal essential medium containing 5\% calf serum treated three times with dextrancoated charcoal), then followed by culturing the cells in whole serum medium in the absence of fulvestrant for more than 12 months. 4-Hydroxytamoxifen, estradiol, mitoxantrone, doxorubicin and paclitaxel were purchased from Sigma-Aldrich (St. Louis, MO). FTC was purchased from Axxora, LLC (San Diego, CA). Gefitinib was a generous gift from AstraZeneca Pharmaceuticals. Raloxifene was a generous gift from Lilly Research Laboratories (Indianapolis, IN).

Western blot analysis. Whole-cell lysate was extracted in modified RIPA buffer (1X PBS, 0.1\% SDS, 1\% NP-40, $0.5 \%$ sodium deoxycholate, $1 \mathrm{mM}$ EGTA, $2.5 \mathrm{mM}$ EGTA, 10\% glycerol, and $10 \mathrm{mM}$ B-glycerophosphate) with a protease inhibitor cocktail and a phosphatase inhibitor cocktail (SigmaAldrich). Protein concentration was measured with a Bio-Rad protein assay kit (Bio-Rad Laboratories, Hercules, CA). Antibodies against ER $\alpha$, total EGFR, $\beta$-actin and $\alpha$-tubulin were purchased from Santa Cruz Biotechnology (Santa Cruz, CA). Antibodies against phospho-EGFR ${ }^{\mathrm{Y} 1173}$, phospho-Akt ${ }^{\mathrm{Ser} 467}$, total Akt, phospho-MAPK ${ }^{44 / 42}$ and total MAPK M4/42 were $^{44}$ purchased from Cell Signaling (Boston, MA). Anti-BCRP antibody was purchased from Axxora, LLC. The appropriate secondary antibody conjugated to horseradish peroxidase (Santa Cruz Biotechnology) was used to visualize bands with an enhanced chemiluminescence (ECL) visualization kit (Amersham, Arlington Heights, IL).

Cell growth assays. Both MCF-7 and MCF-7/F cells were grown in estrogen-free medium for 4 days before the assay began. Ten thousand cells per well were seeded in 24-well plates. The cells were treated in estrogen-free medium containing different concentrations of different chemicals as shown in figures every other day for 7 days. The DNA content of cells was measured using a DNA quantitation kit (Bio-Rad Laboratories) with a Mithras LB 940 microlabel reader (Berthold Technologies, Oak Ridge, TN).

Transient transfection and luciferase assays. MCF-7 and $\mathrm{MCF}-7 / \mathrm{F}$ cells were cultured in the estrogen-free medium for 4 days. Five million cells were mixed with $1 \mu \mathrm{g}$ of $\mathrm{Vit}_{2^{-}}$ ERE $_{3}$-Luciferase (VitA $A_{2}$ is vitellogenin $A_{2}$ and $E_{2} E_{3}$ is three copies of estrogen response elements) (14) and $0.25 \mu \mathrm{g}$ of pRL-TK (Promega, Madison, WI). pRL-TK served as an internal control for transfection efficiency. Cells were electroporated $(950 \mu \mathrm{F}, 320 \mathrm{~V})$ with a Bio-Rad Gene Pulser II (BioRad Laboratories). Luciferase activities were measured using a Dual-Luciferase ${ }^{\circledR}$ reporter assay system (Promega) with a Mithras LB 940 microlabel reader. The results are presented as relative light unit $(\mathrm{RLU})=$ Firefly luciferase reading/Renilla luciferase reading.

Reverse transcription and real-time polymerase chain reaction. Reverse transcription and real-time PCR was performed as described previously (15). 18S rRNA primers and probe were purchased from Applied Biosystems (Foster City, CA). Sequences for $\mathrm{ER} \alpha, \mathrm{ER} \beta$ and EGFR primers and probes were published previously (16). ER $\alpha, E R ß$ and EGFR primers and probes were synthesized by MegaBases (Evanston, IL).

Statistical analysis. All data are represented as the mean \pm SD of three independent determinations in one representative experiment. Each experiment was repeated at least three times unless otherwise stated. The statistical significance $(\mathrm{p}<0.05)$ was determined with a One-way variance analysis followed by Tukey's test if there are more than 3 groups of conditions (GraphPad Prism 3.0, GraphPad Software Inc. San Diego, CA). Student's t-test was used to determine the significance at level $\mathrm{p}<0.05$ when only two groups were compared. All statistical tests were 2-sided.

\section{Results}

Loss of ERa expression in MCF-7/F cells. To understand fulvestrant resistance and identify future therapeutic targets, we developed a fulvestrant-resistant breast cancer cell model (MCF-7/F) derived from MCF-7 cells as described in Materials and methods. MCF-7 parental cells are ER $\alpha$ positive. Estradiol stimulated growth and antiestrogens such as fulvestrant and raloxifene inhibited estradiol-stimulated growth in MCF-7 cells (Fig. 1). However, MCF-7/F cells grew in the absence of estradiol in a time-dependent manner (Fig. 1A) and grew independent of estrogen or antiestrogen treatment (Fig. 1B). To 
A

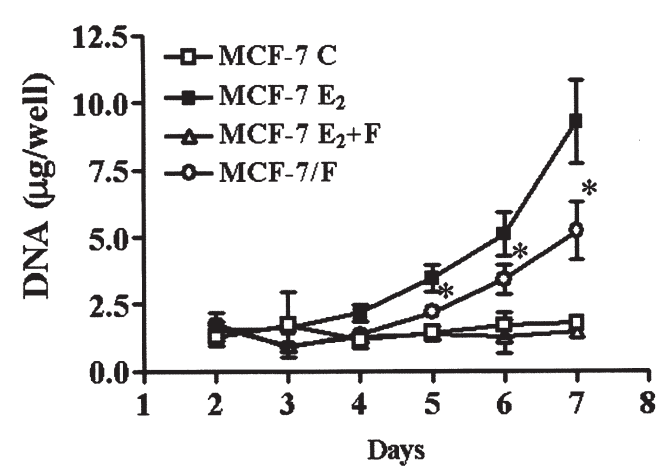

B

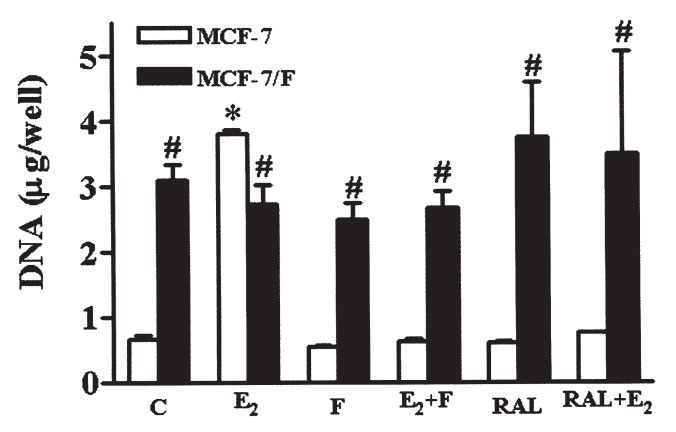

Figure 1. Characteristics of cell growth in MCF-7 and MCF-7/F cells. (A) Time-dependent growth of MCF-7 and MCF-7/F cells. MCF-7 cells were treated with ethanol (MCF-7 C), $1 \mathrm{nM}$ estradiol (MCF-7 $\mathrm{E}_{2}$ ), or combination of $1 \mathrm{nM} \mathrm{E}_{2}+1 \mu \mathrm{M}$ fulvestrant $\left(\mathrm{MCF}-7 \mathrm{E}_{2}+\mathrm{F}\right)$. MCF-7/F cells were treated with $1 \mu \mathrm{M}$ fulvestrant. *Compared with MCF-7 C, MCF-7 $\mathrm{E}_{2}$, or MCF-7 $\mathrm{E}_{2}+\mathrm{F}$ group, $\mathrm{p}<0.05$. (B) Hormone-dependent growth of MCF-7 and MCF-7/F cells. Both MCF-7 and MCF-7/F cells were treated with ethanol (C), $1 \mathrm{nM}$ $\mathrm{E}_{2}, 1 \mu \mathrm{M}$ fulvestrant $(\mathrm{F}), 1 \mathrm{nM} \mathrm{E} \mathrm{E}_{2}+1 \mu \mathrm{M}$ fulvestrant $\left(\mathrm{E}_{2}+\mathrm{F}\right), 1 \mu \mathrm{M}$ raloxifene (RAL), or $1 \mathrm{nM} \mathrm{E}_{2}+1 \mu \mathrm{M}$ raloxifene $\left(\mathrm{RAL}+\mathrm{E}_{2}\right)$. ${ }^{*}$ Compared with any other

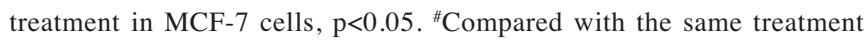
group in MCF-7 cells, $\mathrm{p}<0.05$.

determine how MCF-7/F cells became hormone-independent, we measured ER $\alpha$ expression by Western blot analysis, immunohistochemical staining, real-time PCR, and ER transcriptional activity by a transient transfection assay using a VitA $\mathrm{ERE}_{3}$-Luciferase reporter gene. Short-term treatment (24 h) with $1 \mu \mathrm{M}$ fulvestrant dramatically decreased ER $\alpha$ protein level in MCF-7 cells (Fig. 2A, lane 2). However, ER $\alpha$ mRNA was detectable (66.7\% of the ethanol control, Fig. 2B, left panel, lane 2). After withdrawal of fulvestrant for over one year, $\mathrm{MCF}-7 / \mathrm{F}$ cells remained $\mathrm{ER} \alpha$ negative as determined by Western blot analysis (Fig. 2A, lane 3) and immunochemical staining (data not shown). ER $\alpha$ mRNA level was 120 times lower than that of MCF-7 control (Fig. 2B, left panel, lane 3). There was no significant increase in expression of ERß as measured by real-time PCR (Fig. 2B, right panel). Thus, we excluded a role for ERß in fulvestrant-resistance in $\mathrm{MCF}-7 / \mathrm{F}$ cells. In addition, ER transcriptional activity was very low and hormone-independent in MCF-7/F cells (Fig. 2C). These results demonstrated that there was no functional ER ( $\alpha$ and $\beta$ ) expressed in MCF-7/F cells after long-term withdrawal of fulvestrant. We conclude that MCF-7/F cells irreversibly lost $\mathrm{ER} \alpha$ expression and became hormone-independent with resistance to fulvestrant.
A
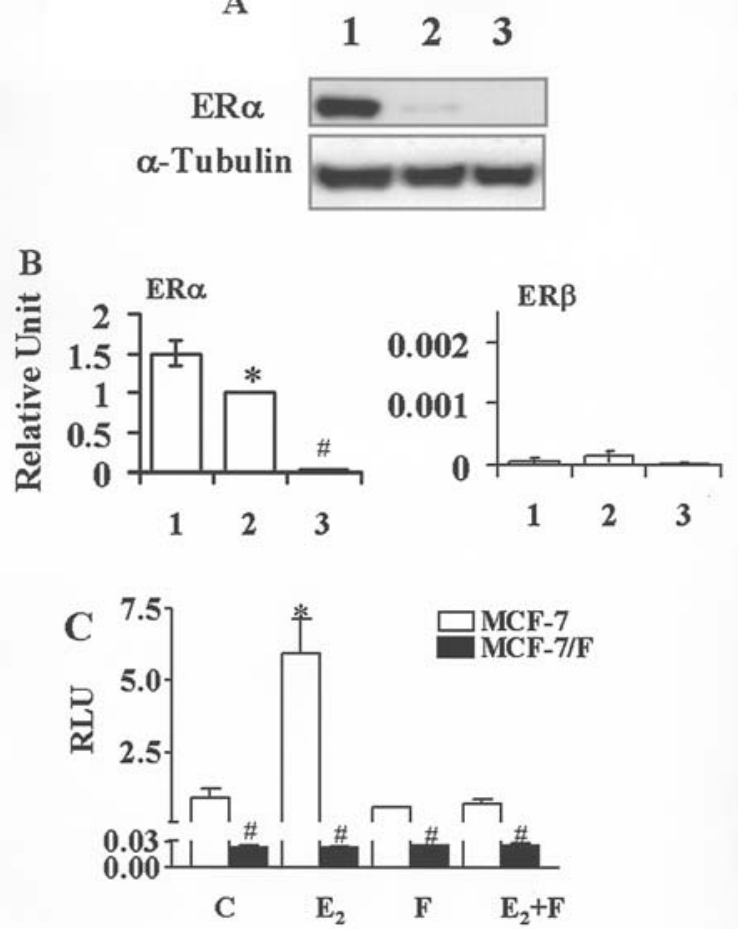

Figure 2. Loss of functional ER expression in MCF-7/F cells. (A) Western blot analysis of ER $\alpha$ protein levels in MCF-7 cells treated with ethanol (1) or $1 \mu \mathrm{M}$ fulvestrant (2), and MCF-7/F cells treated with ethanol (3) for $24 \mathrm{~h}$. Both cells were cultured in estrogen-free medium for 4 days before the experiment. $\alpha$-Tubulin was used as the loading control. (B) Real-time PCR analysis of $E R \alpha$ (left panel) and ERß (right panel) mRNA expression in MCF-7 cells treated with ethanol (1) or $1 \mu \mathrm{M}$ fulvestrant (2), and MCF-7/F cells treated with ethanol (3) for $24 \mathrm{~h}$. Relative units are expressed as fold related to MCF-7 treated with $1 \mu \mathrm{M}$ fulvestrant. "Compared with MCF-7 control, $\mathrm{p}<0.05$. "Compared with MCF-7 control and $1 \mu \mathrm{M}$ fulvestrant groups, $\mathrm{p}<0.05$. ERß mRNA was almost undetectable in all groups. (C) Transient transfection and luciferase assays. The cells were transfected with $V$ it $\mathrm{A}_{2}-\mathrm{ERE}_{3}$ luciferase and pRL-TK, followed by treatment with ethanol (C), $1 \mathrm{nM}$ estradiol $\left(\mathrm{E}_{2}\right), 1 \mu \mathrm{M}$ fulvestrant $(\mathrm{F})$, or combination of $1 \mathrm{nM} \mathrm{E} \mathrm{E}_{2}$ and $1 \mu \mathrm{M}$ fulvestrant $\left(\mathrm{E}_{2}+\mathrm{F}\right)$ for $24 \mathrm{~h}$. ${ }^{*}$ Compared with $\mathrm{MCF}-7$ cells treated with $\mathrm{C}, \mathrm{F}$, or $\mathrm{E}_{2}+\mathrm{F}, \mathrm{p}<0.05$. ${ }^{*}$ Compared with $\mathrm{MCF}-7$ cells with the same treatment, $\mathrm{p}<0.05$.

Growth inhibition by gefitinib via inhibiting phosphorylation of MAPK ${ }^{4 / 42}$ and Akt in MCF-7/F cells. It is well documented that EGFR expression inversely relates to ER $\alpha$ expression $(17,18)$ and has been frequently reported that increased expression of EGFR accompanies antiestrogen resistance $(10,11,19,20)$. Thus, it is not surprising that EGFR was highly expressed in MCF-7/F cells at both mRNA (Fig. 3B) and protein (Fig. 3A) levels. The EGFR gene was not amplified in $\mathrm{MCF}-7 / \mathrm{F}$ cells as determined by fluorescence in situ hybridization (data not shown). Overexpressed EGFR in $\mathrm{MCF}-7 / \mathrm{F}$ cells might be a potential target for the treatment of fulvestrant-resistant breast cancer.

To determine whether overexpressed EGFR had any effect on cell growth in MCF-7/F cells, we used an EGFR kinase specific inhibitor, gefitinib. Gefitinib had no significant effect on $\mathrm{E}_{2}$-induced cell growth in MCF-7 cells. However, gefitinib inhibited cell growth in MCF-7/F cells in a concentrationdependent manner (Fig. 4A). These results indicate that the overexpressed EGFR has an important growth promoting effect in MCF-7/F cells and EGFR could be a potential target in breast cancer after failure on fulvestrant. To further investigate 
A

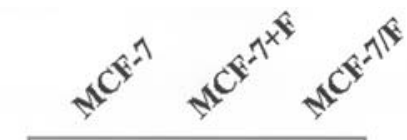

EGFR

$\alpha$-Tubulin

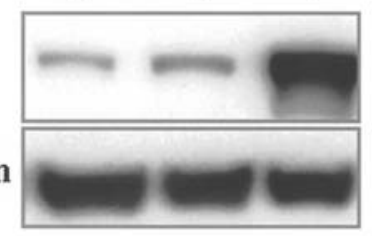

B

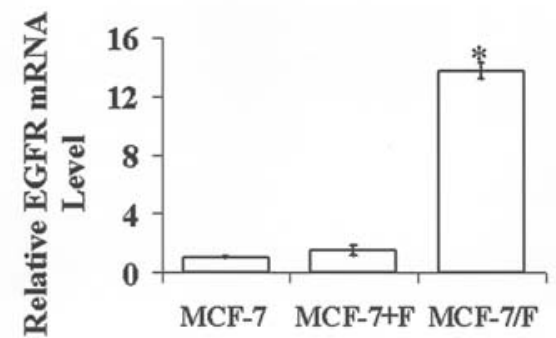

Figure 3. Expression of EGFR in MCF-7/F cells. (A) EGFR expression was measured by Western blot analysis. (B) Real-time PCR. MCF-7 cells were treated with ethanol control (MCF-7) or $1 \mu \mathrm{M}$ fulvestrant (MCF-7+F) for $24 \mathrm{~h}$. MCF-7/F cells were treated with ethanol for $24 \mathrm{~h} .{ }^{*}$ Compared to MCF-7 and MCF-7+F, $\mathrm{p}<0.05$. how gefitinib differentially inhibited the growth of MCF-7/F cells, we found that phosphorylated EGFR ${ }^{\mathrm{Y} 1173}$ is barely detectable in MCF-7 cells (Fig. 4B). In contrast, MCF-7/F cells showed much higher phosphorylation of EGFR detected by anti-phospho-EGFR ${ }^{\mathrm{Y} 1173}$ (Fig. 4B) and anti-phospho-

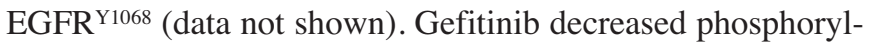
ation of EGFR in MCF-7/F cells. MAPK ${ }^{4 / 42}$ and Akt are the two important downstream factors for EGFR signal transduction pathway $(21,22)$. Although total protein levels of MAPK ${ }^{44 / 42}$ and Akt were much lower, phosphorylation of both MAPK ${ }^{44 / 42}$ and Akt were clearly increased in MCF-7/F cells (Fig. 4B), suggesting that the growth and survival of MCF-7/F cells might be predominantly dependent on MAPK $^{4 / 42}$ and Akt pathways. Gefitinib inhibited phosphorylation of MAPK ${ }^{44 / 42}$ in both MCF-7 and MCF-7/F cells (Fig. 4B). However, gefitinib inhibited phosphorylation of Akt in a concentration-dependent manner only in MCF-7/F cells. U0126, an inhibitor of MEK (the upstream activator of MAPK $^{44 / 42}$ ), inhibited cell growth in a concentration-dependent manner in both MCF-7 and MCF-7/F cells but the inhibitory effect of $\mathrm{U} 0126$ at concentrations from 0.625 to $5 \mu \mathrm{M}$ was significantly more apparent in MCF-7/F cells than parental MCF-7 cells (Fig. 4C). Similarly, MCF-7/F cells were more sensitive to Ly294002, an inhibitor of PI3K (one of the
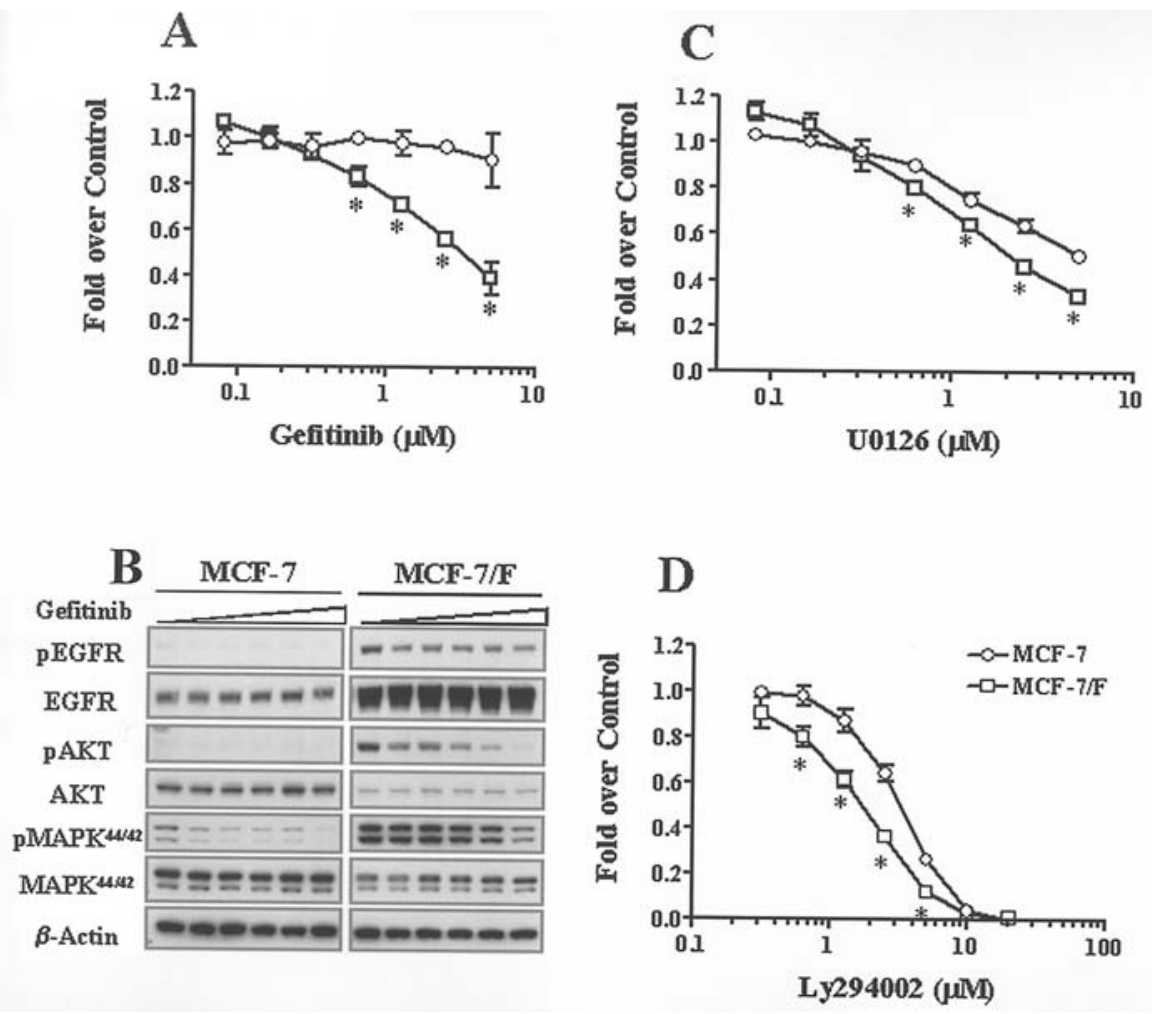

Figure 4. Effect of gefitinib on cell growth and EGFR signaling pathway in MCF-7 and MCF-7/F cells. (A) DNA assay to measure effect of gefitinib on cell growth. MCF-7 ( ) and MCF-7/F ( $\square$ ) cells were treated with increasing concentrations (control, 0.08, 0.16, 0.31, 0.63, 1.25, 2.50, 5.00 $\mu \mathrm{M}$ ) of gefitinib in the presence of $5 \times 10^{-12} \mathrm{M}$ of estradiol for 7 days. The results are presented as fold over $5 \times 10^{-12} \mathrm{M}$ of estradiol alone group (fold over control). ${ }^{*}$ Compared to the same treatment group in MCF-7 cells, p $<0.05$. (B) Western blot analysis to determine the effect of gefitinib on EGFR signaling pathway. The cells were treated with increasing concentrations (control, $0.31,0.63,1.25,2.50,5.00 \mu \mathrm{M}$ ) of gefitinib in the presence of $5 \times 10^{-12} \mathrm{M}$ estradiol for $24 \mathrm{~h}$. $\beta$-actin was used as the internal loading control. (C) Concentration-dependent effect of U0126 on cell growth. MCF-7 and MCF-7/F cells were treated with increasing concentrations (control, $0.08,0.16,0.31,0.63,1.25,2.50$, or $5.00 \mu \mathrm{M})$ of U0126 in combination with $5 \times 10^{-12} \mathrm{M}$ estradiol for 7 days. The results are presented as fold over $5 \times 10^{-12} \mathrm{M}$ of estradiol alone group (fold over control). ${ }^{*}$ Compared to the same treatment groups in MCF-7 cells, $\mathrm{p}<0.05$. (D) Concentration-dependent effect of Ly294002 on cell growth. MCF-7 and MCF-7/F cells were treated with increasing concentrations (control, 0.31, 0.63, 1.25, 2.50, 5.00, 10.00, or 20.00 $\mu \mathrm{M}$ ) of Ly294002 in combination with $5 \times 10^{-12} \mathrm{M}$ estradiol for 7 days. The results are presented as fold over $5 \times 10^{-12} \mathrm{M}$ of estradiol alone group (fold over control). ${ }^{*}$ Compared to the same treatment groups in MCF-7 cells, $\mathrm{p}<0.05$. 


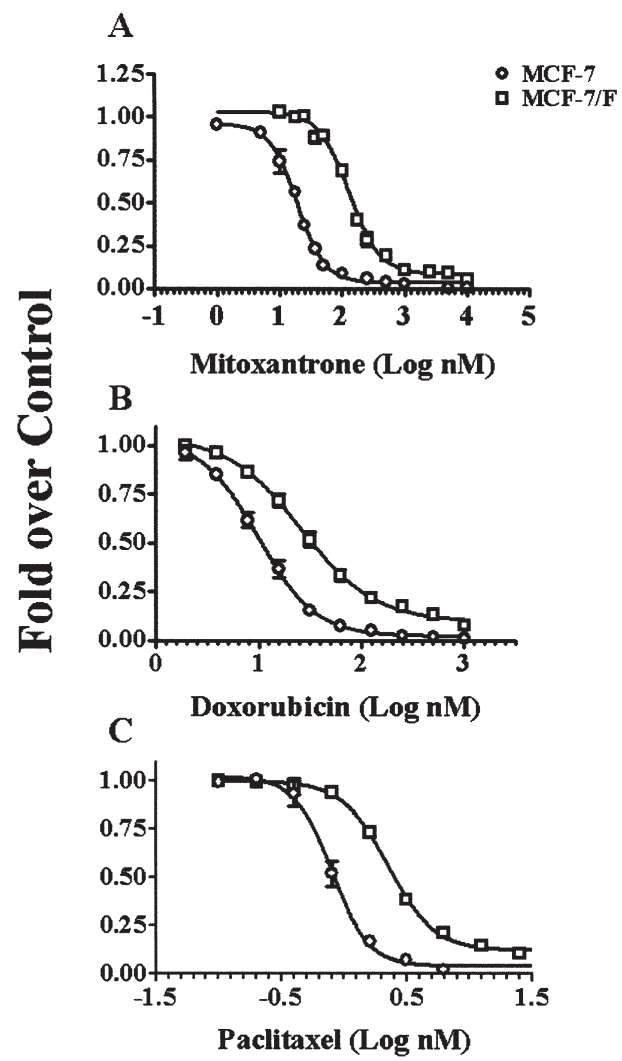

Figure 5. Decreased chemosensitivity in MCF-7/F cells. Sensitivity to chemotherapeutics such as (A) mitoxantrone, (B) doxorubicin, or (C) paclitaxel was determined by DNA assays. The cells were treated with increasing concentrations of mitoxantrone, doxorubicin, or paclitaxel in the presence of $5 \times 10^{-12} \mathrm{M}$ estradiol for 7 days. The data are presented as fold over $5 \times 10^{-12} \mathrm{M}$ of estradiol alone group (fold over control).

upstream activators of Akt) (Fig. 4D). These results suggest that $\mathrm{MAPK}^{44 / 42}$ and Akt pathways were more important for survival and growth in MCF-7/F cells, and gefitinib inhibited cell growth by inhibiting phosphorylation of $\mathrm{MAPK}^{44 / 42}$ and Akt in $\mathrm{MCF}-7 / \mathrm{F}$ cells.

Chemotherapeutic insensitivity due to overexpression of $B C R P$ in $M C F-7 / F$ cells. After $\mathrm{ER} \alpha$ positive tumors fail fulvestrant and become ER $\alpha$ negative, cytotoxic chemotherapy is the treatment of choice. To quantify the impact of fulvestrant resistance on chemosensitivity we compared the effect of a number of chemotherapeutic agents on the growth of MCF-7 and MCF-7/F cells using a DNA assay. As shown in Fig. 5, the $\mathrm{IC}_{50}$ for mitoxantrone increased 6.8 -fold $(\mathrm{p}<0.05)$ in MCF-7/F cells $(135.1 \pm 7.1 \mathrm{nM})$ compared to MCF-7 cells $(17.8 \pm 2.0 \mathrm{nM})$ (Fig. 5A), the $\mathrm{IC}_{50}$ for doxorubicin significantly $(\mathrm{p}<0.05)$ increased from $10.5 \pm 1.8 \mathrm{nM}$ in MCF-7 to 29.6 $\pm 4.6 \mathrm{nM}$ in $\mathrm{MCF}-7 / \mathrm{F}$ cells (Fig. 5B), and the sensitivity to paclitaxel significantly decreased in $\mathrm{MCF}-7 / \mathrm{F}$ cells $\left(\mathrm{IC}_{50}=\right.$ $2.3 \pm 0.04 \mathrm{nM})$ compared to MCF-7 cells $\left(\mathrm{IC}_{50}=0.8 \pm 0.1 \mathrm{nM}\right.$, $\mathrm{p}<0.05)$ (Fig. 5C).

There are three major multidrug-resistant genes, namely, p-glycoprotein (P-gp/ABCB1/MDR1/PGY1), multiple drug resistant protein $(\mathrm{MRP} / \mathrm{ABCC} 1)$ and breast cancer resistant protein (BCRP/ABCG2//ABCP/MXR) (23). We found that $\mathrm{P}-\mathrm{gp}$ and MRP were expressed at similar levels in MCF-7

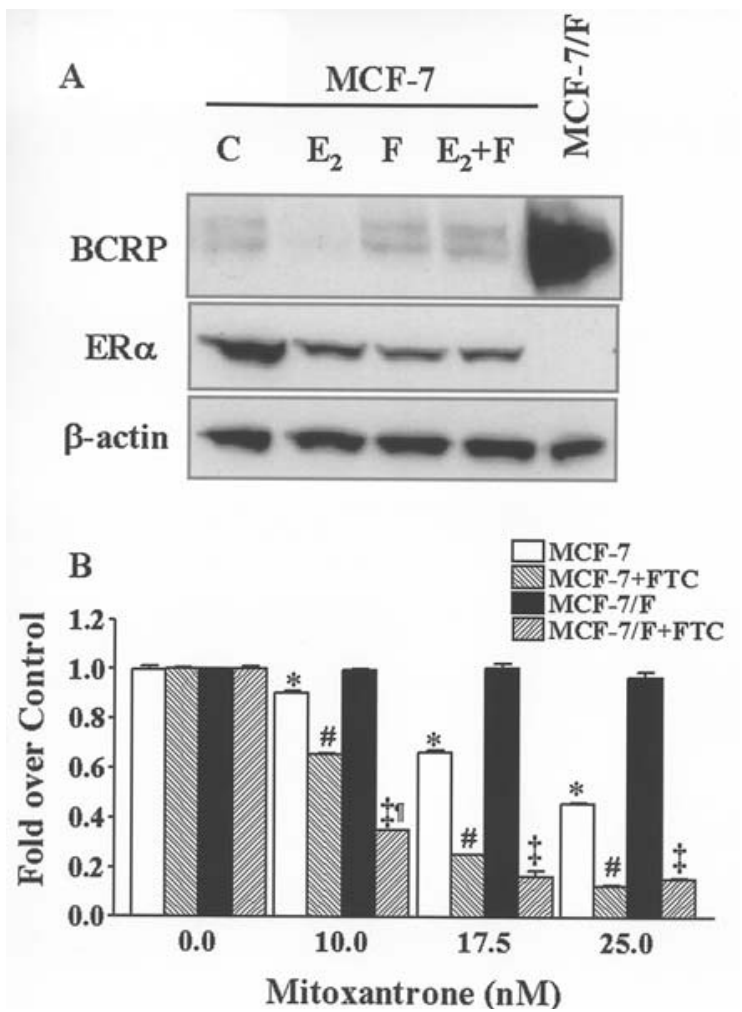

Figure 6. The effect of BCRP overexpression on chemosensitivity in MCF and MCF-7/F cells. (A) BCRP expression was determined by Western blot analysis. MCF-7 cells were treated with ethanol (C), $5 \times 10^{-12} \mathrm{M}$ estradiol $\left(\mathrm{E}_{2}\right), 1 \mu \mathrm{M}$ fulvestrant $(\mathrm{F})$ or combination of $5 \times 10^{-12} \mathrm{M} \mathrm{E}_{2}$ and $1 \mu \mathrm{M}$ fulvestrant $\left(E_{2}+F\right)$ for $24 \mathrm{~h}$. MCF-7/F cells were treated with ethanol for $24 \mathrm{~h}$. ß-actin was used as the loading control. (B) Inhibiting BCRP activity by $2.5 \mu \mathrm{M}$ FTC enhanced the inhibitory effect of mitoxantrone on cell growth in MCF-7/F cells. The data are presented as fold of control (absence of mitoxantrone). *Compared to MCF-7 in the absence of mitoxantrone, $\mathrm{p}<0.05$. "Compared to the same mitoxantrone treatment in the absence of FTC in MCF-7 cells, p<0.05. ${ }^{\ddagger}$ Compared to the same mitoxantrone treatment without FTC in MCF-7/F cells, $\mathrm{p}<0.05$. "Compared to the same mitoxantrone treatment in MCF-7+FTC, $\mathrm{p}<0.05$.

and MCF-7/F cells, but BCRP was overexpressed in MCF-7/F cells by a DNA microarray assay (unpublished data). Overexpression of BCRP was confirmed by Western blot analysis (Fig. 6A). To determine whether the observed decreased sensitivity to chemotherapeutics was due to overexpression of BCRP, we treated MCF-7 and MCF-7/F cells with different concentrations of mitoxantrone alone or in combination with $2.5 \mu \mathrm{M}$ of FTC, a BCRP-specific inhibitor (12). FTC had no effect on cell growth in MCF-7 and MCF-7/F cells at a concentration as high as $10 \mu \mathrm{M}$ (data not shown). The results in Fig. 6B show that mitoxantrone inhibited cell growth in MCF-7 cells in a concentration-dependent manner as demonstrated in more detail in Fig. 5A. Although MCF-7 cells expressed low levels of BCRP protein (Fig. 6A), $2.5 \mu \mathrm{M}$ of FTC significantly enhanced the effect of mitoxantrone on inhibiting cell growth. In MCF-7/F cells, mitoxantrone had little effect on cell growth at $25.0 \mathrm{nM}$. Mitoxantrone, at concentrations of 17.5 and $25.0 \mathrm{nM}$, in combination with $2.5 \mu \mathrm{M}$ of FTC inhibited cell growth to the same extent in $\mathrm{MCF}-7 / \mathrm{F}$ cells as observed in MCF-7 cells (Fig. 6B). Interestingly, $10.0 \mathrm{nM}$ mitoxantrone with $2.5 \mu \mathrm{M}$ FTC inhibited the growth of MCF-7/F cells significantly more than in 

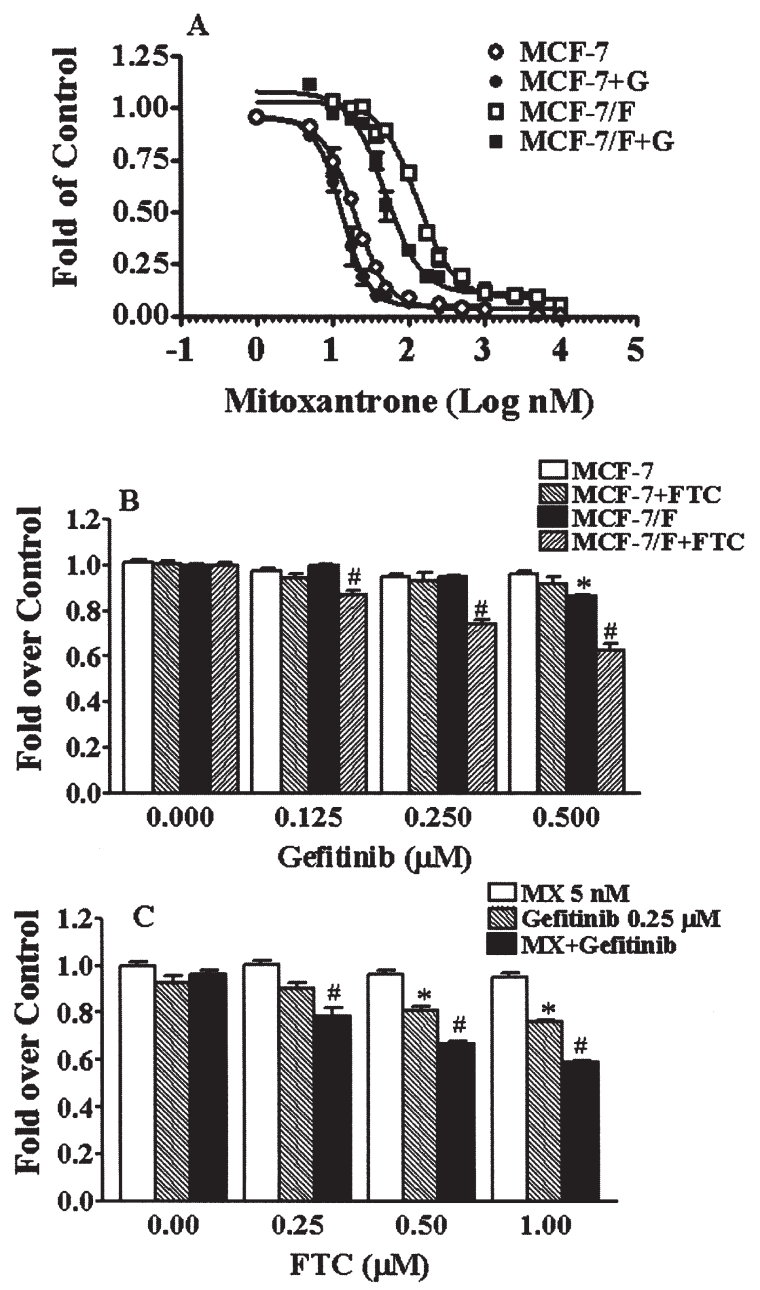

Figure 7. The cooperative effect of mitoxantrone, gefitinib and FTC on cell growth in MCF-7 and MCF-7/F cells. (A) Gefitinib augmented the inhibitory effect of mitoxantrone on cell growth in MCF-7/F cells. Both MCF-7 and MCF-7/F cells were treated with increasing concentrations of mitoxantrone $(0.001-10 \mu \mathrm{M})$ plus $5 \times 10^{-12} \mathrm{M}$ estradiol in the absence or presence of $0.5 \mu \mathrm{M}$ gefitinib for 7 days. The data are presented as fold over control $\left[5 \times 10^{-12} \mathrm{M}\right.$ estradiol for MCF-7 (०) and MCF-7/F ( $\square$ ), $5 \times 10^{-12} \mathrm{M}$ estradiol $+0.5 \mu \mathrm{M}$ gefitinib for MCF-7+G $(\bullet)$ and MCF-7/F+G $(\bullet)]$. The results shown are from two separate experiments. (B) FTC enhanced the inhibitory effect of gefitinib on cell growth in MCF-7/F cells. Both MCF-7 and MCF-7/F cells were treated with different concentrations of gefitinib (as shown) plus $5 \times 10^{-12} \mathrm{M}$ estradiol with or without $2.5 \mu \mathrm{M}$ FTC for 7 days. The results shown are from two independent experiments and presented as fold over control (groups in the absence of gefitinib). "Compared to MCF-7/F cells in the absence of gefitinib, $\mathrm{p}<0.05 .{ }^{~ " C o m p a r e d ~ t o ~ M C F-7 / F ~ c e l l s ~}$ treated with the same concentration of gefitinib in the absence of FTC, $\mathrm{p}<0.05$. (C) The inhibitory effect of $5 \mathrm{nM}$ mitoxantrone (MX $5 \mathrm{nM}$ ), $0.25 \mu \mathrm{M}$ gefitinib (gefitinib $0.25 \mu \mathrm{M}$ ), or $5 \mathrm{nM}$ mitoxantrone $+0.25 \mu \mathrm{M}$ gefitinib (MX + gefitinib) was increased by low concentrations of FTC $(0-1.00 \mu \mathrm{M})$ in MCF-7/F cells. "Compared to $0.25 \mu \mathrm{M}$ gefitinib alone, $\mathrm{p}<0.05$. "Compared to the other two treatments with the same concentration of FTC, p $<0.05$.

MCF-7 cells $(p<0.05)$. Thus, we concluded that the decreased sensitivity to mitoxantrone in MCF-7/F cells is BCRPmediated.

Cooperative effect of gefitinib, mitoxantrone, and FTC in $M C F-7 / F$ cells. It has recently been reported that gefitinib reverses BCRP-mediated drug resistance in BCRP-transfected MCF-7 cells (24), human epidermoid carcinoma A431 cells, human leukemia K562 cell, and human colon cancer HT-29 cells which endogenously express BCRP (25). There are no reports of a fulvestrant-resistant breast cancer cell model overexpressing endogenous BCRP. We investigated whether gefitinib affects chemosensitivity mediated by endogenously expressed BCRP in MCF-7/F cells. 0.5 $\mu \mathrm{M}$ gefitinib slightly decreased $\mathrm{IC}_{50}$ for mitoxantrone from $17.8 \pm 2.0$ to $13.3 \pm 1.3 \mathrm{nM}$, ( $>0.05$ ) in MCF-7 cells (Fig. 7A). However, $0.5 \mu \mathrm{M}$ gefitinib significantly shifted the concentration-dependent curve of mitoxantrone to the left, and $\mathrm{IC}_{50}$ for mitoxantrone changed from 135.1 \pm 7.1 to $48.0 \pm 6.5 \mathrm{nM}(\mathrm{p}<0.05)$ in $\mathrm{MCF}-7 / \mathrm{F}$ cells (Fig. 7A). Thus, gefitinib did enhance the inhibitory effect of mitoxantrone in MCF-7/F cells endogenously overexpressing BCRP, although it did not completely reverse BCRP-mediated chemoresistance.

Overexpression of BCRP not only causes chemoresistance, but is also reported to decrease gefitinib efficacy (26). We investigated whether blocking BCRP with FTC affects the inhibitory effect of gefitinib on cell growth in MCF-7/F cells. Fig. 7B shows that up to a $0.5-\mu \mathrm{M}$ concentration gefitinib had no significant effect on cell growth in MCF-7 cells; $2.5 \mu \mathrm{M}$ FTC did not affect the inhibitory effect of gefitinib in MCF-7 cells. Interestingly, gefitinib, with $2.5 \mu \mathrm{M}$ FTC, inhibited cell growth significantly at a concentration as low as $0.125 \mu \mathrm{M}$ in MCF-7/F cells, indicating that overexpression of BCRP decreased sensitivity to gefitinib treatment in MCF-7/F cells.

We further treated MCF-7 and MCF-7/F cells with a combination of very low concentrations of mitoxantrone $(5 \mathrm{nM})$, gefitinib $(0.25 \mu \mathrm{M})$, or mitoxantrone $(5 \mathrm{nM})+$ gefitinib $(0.25 \mu \mathrm{M})$ in the absence $(0)$, or presence of low concentrations of FTC $(0.25 \mu \mathrm{M}, 0.50 \mu \mathrm{M}$, or $1.00 \mu \mathrm{M})$. None of the treatments had a significant effect on cell growth in MCF-7 cells (data not shown). As shown in Fig. 7C, treatment with $5 \mathrm{nM}$ mitoxantrone, $0.25 \mu \mathrm{M}$ gefitinib, or $5 \mathrm{nM}$ mitoxantrone $+0.25 \mu \mathrm{M}$ gefitinib did not significantly affect cell growth in the absence of FTC. However, FTC $(0.25$, 0.50 or $1.00 \mu \mathrm{M}$ ) significantly increased the efficacy of mitoxantrone + gefitinib.

\section{Discussion}

The goal of our study was to describe the therapeutic consequences of the prolonged treatment of ER-positive breast cancer cells with fulvestrant in a low-estrogen environment. We have found that the cells lose ER during antihormone therapy and become resistant to both antihormones and cytotoxic chemotherapy. The fulvestrant-resistant cells (MCF-7/F) were stable and remained ER $\alpha$ negative during the one year observation period following withdrawal of fulvestrant from culture medium. In addition, MCF-7/F cells overexpressed EGFR and BCRP. These targets were found to interact and could be modulated to improve sensitivity to cytotoxic chemotherapy.

We report the characterization of a unique fulvestrantresistant ER $\alpha$ negative cell line (MCF-7/F) derived from the parental MCF-7 ER $\alpha$-positive human breast cancer cells. Fulvestrant inhibited cell growth significantly at a concentration as low as $0.01 \mu \mathrm{M}$ in MCF-7 cells (data not shown). In contrast, MCF-7/F cells grew in $1 \mu \mathrm{M}$ fulvestrantcontaining medium in the absence or presence of $1 \mathrm{nM} \mathrm{E}_{2}$ (Fig. 1). However, fulvestrant did decrease the cell number at 
a $10-\mu \mathrm{M}$ concentration in MCF-7/F cells (data not shown), which might result from a non-specific cytotoxic effect with such a high concentration of the compound. Since MCF-7/F cells were ER $\alpha$ negative (Fig. 2A and B, left panel) with no significant change of expression level of ERß (Fig. 2B, right panel), it was not surprising that MCF-7/F cells exhibited cross-resistance to raloxifene (Fig. 1B) and 4-hydroxytamoxifen (data not shown). We also speculate that aromatase inhibitors would not have any effect on the growth of fulvestrant-resistant breast cancer because they are ER $\alpha$ negative and continue to grow in estrogen-free media. Our preliminary results (data not shown) did not support that DNA methylation or histone deacetylation played major roles in $\mathrm{ER} \alpha$ negativity in MCF-7/F cells. However, the precise mechanism for the loss of ER $\alpha$ expression in $\mathrm{MCF}-7 / \mathrm{F}$ cells is still unclear.

EGFR expression inversely relates to ER $\alpha$ expression $(17,18)$. It has been reported that increased expression of EGFR accompanies antiestrogen resistance $(10,11,19,20)$. Gefitinib, an EGFR tyrosine kinase inhibitor, inhibits the growth of antiestrogen-resistant breast cancer $(10,19)$, enhances the growth inhibitory effect of antiestrogens and prevents the development of antiestrogen resistance (27-29). Since MCF-7/F cells were ER $\alpha$ negative, we anticipated that MCF-7/F cells overexpressed EGFR (Fig. 3) and addressed the proposition that elevated EGFR might have an important role in cell survival and growth in MCF-7/F cells. Although elevated EGFR level is not a good predicator for response to gefitinib (30), gefitinib has been reported to inhibit the growth of tamoxifen-resistant and fulvestrant-resistant cell lines in vitro that exhibited enhanced EGFR signal transduction $(10,19)$. We compared the inhibitory effect of gefitinib on cell growth in MCF-7 and MCF-7/F cells in the presence of estrogen. Although EGF stimulated the growth of MCF-7 cells in serum-free condition (data not shown), ER $\alpha$ signaling pathway might be the predominant cell growth promoting pathway in MCF-7 cells when estradiol is present. It was not surprising that gefitinib slightly, but not significantly $(\mathrm{p}>0.05)$, inhibited estrogen-induced growth in MCF-7 cells at a $5-\mu \mathrm{M}$ concentration (Fig. 4A). However, gefitinib profoundly inhibited cell growth of MCF-7/F cells at a concentration as low as $0.625 \mu \mathrm{M}$ (Fig. 4A). The results indicate that while cell growth and survival of MCF-7 cells largely rely on the $\mathrm{ER} \alpha$ signal transduction pathway, MCF-7/F cells are at least partially dependent on the EGFR pathway. Enhanced activation of EGFR downstream factors MAPK ${ }^{44 / 42}$ and Akt (Fig. 4B) made MCF-7/F cells more susceptible to the inhibitory effects of U0126 and Ly294002 (Fig. 4C and D), which further illustrate the important role of EGFR signaling in MCF-7/F cell growth. Gefitinib inhibited MAPK ${ }^{44 / 42}$ phosphorylation in parental MCF-7 cells (Fig. 4B) without showing significant inhibition of cell growth (Fig. 4A), which is consistent with the lower sensitivity to U0126 in MCF-7 cells. We also studied the possible role of other ErbB family members in fulvestrant-resistance. The total and phosphorylated levels of ErbB2 were increased approximately 2-fold in MCF-7/F compared to MCF-7 cells (data not shown). However, we found that trastuzumab, a humanized monoclonal antibody specific for ErbB2, did not have a significant effect on MCF-7/F cell growth (data not shown). There were no significant changes in the expression of ErbB3 and ErbB4 determined by real-time PCR (data not shown). Overall our results with gefitinib support the hypothesis that growth of $\mathrm{MCF}-7 / \mathrm{F}$ cells occurs, at least in part, via EGFR with downstream MAPK ${ }^{44 / 42}$ and Akt phosphorylation.

Cytotoxic chemotherapy is often the only alternative for patients with endocrine-resistant ER $\alpha$-negative tumors. We examined the efficacy of chemotherapeutic drugs such as mitoxantrone, doxorubicin and paclitaxel in parental MCF-7 and MCF-7/F cells. Since chemotherapeutic agents affect rapidly growing cells, we controlled comparable cell growth rate in MCF-7 and MCF-7/F cells by using $5 \times 10^{-12} \mathrm{M}$ of estrogen in assay medium (data not shown). MCF-7/F cells were significantly less sensitive to mitoxantrone, doxorubicin, and paclitaxel (Fig. 5). Consistent with these chemosensitivity results, MCF-7/F cells overexpressed BCRP (Fig. 6). BCRP is a membrane-associated protein in the superfamily of ATP-binding cassette transporters. It effluxes a variety of anticancer drugs such as anthracyclines, anthracenediones, the camptothecins topotecan and SN-38, methotrexate, and flavopiridol (31-34), which results in chemoresistance. We found that estradiol induced BCRP expression at the mRNA level (data not shown) and inhibited BCRP expression at the protein level in MCF-7 cells (Fig. 6B). The effect of estradiol on BCRP expression is still controversial $(35,36)$. To our knowledge MCF-7/F is the first antiestrogen-resistant breast cancer cell model overexpressing BCRP endogenously. To examine whether elevated BCRP plays a role in decreased chemosensitivity in MCF-7/F cells, we used a specific BCRP inhibitor, FTC, to block its activity (37). As shown in Fig. 6B, FTC significantly sensitized MCF-7/F as well as the parental MCF-7 cells to mitoxantrone treatment. This result indicates that the low level of BCRP is functional in terms of decreased chemosensitivity in the parental MCF-7 cells. Interestingly, FTC enhanced the inhibitory effect of $10.0 \mathrm{nM}$ mitoxantrone significantly more in parental MCF-7 cells than in MCF-7/F cells. The reason for this could be based on the mechanism of action of mitoxantrone and the differing mechanisms for regulating apoptosis. Mitoxantrone can induce apoptosis via the mitochondria pathway (38), whereas bcl-2 is an antiapoptotic protein that inhibits mitochondria-mediated apoptosis. We observed that the expression of bcl-2 was stimulated by estrogen in MCF-7 cells, but the bcl-2 protein was not detected in MCF-7/F cells (data not shown). It is therefore possible that estrogen-induced bcl-2 expression might protect parental MCF-7 cells from the FTC-enhanced antitumor effect of mitoxantrone at $10.0 \mathrm{nM}$. It is known that high concentrations of mitoxantrone can decrease bcl-2 expression (39), and eventually overcome estrogen-induced bcl-2 expression. Thus, different survival mechanisms for the different cell lines could potentially explain the actions of FTC.

Interestingly enough, MCF-7/F cells also displayed a decreased sensitivity to paclitaxel (Fig. 5C) that has not been shown to be a substrate for BCRP to transport. FTC did not change the sensitivity to paclitaxel in $\mathrm{MCF}-7 / \mathrm{F}$ cells (data not shown). In contrast, FTC significantly enhanced the sensitivity to doxorubicin in MCF-7/F cells (data not shown). The mechanism by which MCF-7/F cells become insensitive to paclitaxel remains obscure. We compared the expression levels of the two other major multiple drug-resistant genes, 
P-gp and MRP in MCF-7 cells and MCF-7/F cells. Both P-gp and MRP were not overexpressed in MCF-7/F cells (data not shown). ABCC2 (MRP2) was recently reported to mediate paclitaxel resistance (40). However, expression of ABCC2 was not increased significantly in MCF-7/F cells (data not shown).

There is increasing potential for combination therapy with targeted cancer therapy and cytotoxic chemotherapy in breast cancer. The combination of trastuzumab and chemotherapy has been shown to have a synergistic effect in cells overexpressing ErbB2 (41) in vitro and provide clinical benefits for patients with ErbB2 overexpressing breast tumors $(42,43)$. Gefitinib has been shown to potentiate cytotoxic agents such as platinums, cisplatin, carboplatinum, taxanes, doxorubicin, and edatrexate against human skin, lung, and prostate cancer xenografts (44). However, gefitinib did not improve the efficacy of chemotherapeutics in non-small cell lung cancer in two phase III trials $(45,46)$. For breast cancer, a phase I/II clinical trial is currently underway to determine the efficacy of gefitinib, trastuzumab, and docetaxel in combination in patients with ErbB2 overexpressing metastatic breast cancer (ClinicalTrials.gov identifier NCT00086957). Recently, gefitinib has been shown to reverse chemoresistance mediated by BCRP in skin cancer, colon cancer (25), lung cancer, and breast cancer cells (24) which exogenously overexpressed BCRP. Overexpression of BCRP protects cells from gefitinibinduced apoptosis in A431 cells (26), suggesting the possible role of BCRP in resistance to gefitinib. These reports collectively indicate an interaction between gefitinib and BCRP. However, the nature of the interaction is as yet not clear. It is known that gefitinib inhibits BCRP-mediated transport, but gefitinib is not a substrate for BCRP to transport $(24,47)$. In addition, gefitinib has been shown to reverse BCRP-mediated chemoresistance in cells with undetectable levels of EGFR (24). These data suggest a direct effect of gefitinib on BCRP. Nevertheless, BCRP expression affects the efficacy of gefitinib (25) (Fig. 7B), which suggests a possible competitive binding of gefitinib to EGFR and BCRP. Moreover, the other tyrosine kinase inhibitors such as EKI-785, imatinib mesylate, and CI1033 also inhibit BCRP-mediated chemoresistance (48-50). Gefitinib, EKI-785, imatinib mesylate, and CI1033 are all small molecules that compete with ATP for ATP binding sites in receptor tyrosine kinases and inhibit receptor tyrosine kinase activity. Gefitinib has been shown to bind to other tyrosine kinases and even threonine-serine kinases with various affinities $(51,52)$, Thus, it is plausible that the tyrosine kinase inhibitors have various binding affinities to the ATP binding domain in BCRP, block ATP binding, and inhibit BCRP activity.

We were surprised to find that gefitinib is not as effective in MCF-7/F cells as in other EGFR overexpressing cells $(25,51)$. However, the explanation for our observation may involve multiple mechanisms for cancer cell survival. The MCF-7/F cell model is the only tumor cell model so far found to overexpress both endogenous EGFR and BCRP. Although gefitinib did not completely reverse insensitivity to mitoxantrone in MCF-7/F cells (Fig. 7A), inhibiting BCRP by FTC increased the sensitivity to gefitinib in MCF-7/F cells significantly (Fig. 7B). These results suggest that EGFR and BCRP may compete with each other for gefitinib.
Additionally, inhibition of both EGFR and BCRP further enhanced the inhibitory effect of mitoxantrone on cell growth in $\mathrm{MCF}-7 / \mathrm{F}$ cells (Fig. 7C).

In conclusion, we have developed a stable ER $\alpha$ negative breast cancer cell model from ER $\alpha$-positive MCF-7 cells that overexpress both EGFR and BCRP. We have demonstrated that targeting survival mechanisms and an efflux protein can enhance the effectiveness of cytotoxic chemotherapy. Application and translation of these principles to patient care may reduce side effects and enhance the efficacy of cytotoxic chemotherapy in antihormone refractory disease.

\section{Acknowledgements}

This work was supported by NIH SPORE in Breast Cancer CA 89018 (V.C.J.), the Lynn Sage Breast Cancer Research Foundation and the Avon Foundation (V.C.J.).

\section{References}

1. Jensen EV and Jordan VC: The estrogen receptor: a model for molecular medicine. The Dorothy P. London AACR Prize for Translational Research. Clin Cancer Res 9: 1980-1989, 2003.

2. Early Breast Cancer Trialists' Collaborative Group: Effects of chemotherapy and hormonal therapy for early breast cancer on recurrence and 15-year survival: an overview of the randomised trials. Lancet 365: 1687-1717, 2005.

3. Howell A, Robertson JF, Quaresma Albano J, Aschermannova A, Mauriac L, Kleeberg UR, Vergote I, Erikstein B, Webster A and Morris C: Fulvestrant, formerly ICI 182,780, is as effective as anastrozole in postmenopausal women with advanced breast cancer progressing after prior endocrine treatment. J Clin Oncol 20: 3396-3403, 2002.

4. Osborne CK, Pippen J, Jones SE, Parker LM, Ellis M, Come S, Gertler SZ, May JT, Burton G, Dimery I, Webster A, Morris C, Elledge R and Buzdar A: Double-blind, randomized trial comparing the efficacy and tolerability of fulvestrant versus anastrozole in postmenopausal women with advanced breast cancer progressing on prior endocrine therapy: results of a North American trial. J Clin Oncol 20: 3386-3395, 2002.

5. Dauvois S, Danielian PS, White R and Parker MG: Antiestrogen ICI 164,384 reduces cellular estrogen receptor content by increasing its turnover. Proc Natl Acad Sci USA 89: 4037-4041, 1992.

6. Gibson M, Nemmers L, Beckman W Jr, Davis V, Curtis S and Korach K: The mechanism of ICI 164,384 antiestrogenicity involves rapid loss of estrogen receptor in uterine tissue. Endocrinology 129: 2000-2010, 1991.

7. Wakeling AE, Dukes $M$ and Bowler J: A potent specific pure antiestrogen with clinical potential. Cancer Res 51: 3867-3873, 1991.

8. Brunner N, Boysen B, Jirus S, Skaar TC, Holst-Hansen C, Lippman J, Frandsen T, Spang-Thomsen M, Fuqua SA and Clarke R: MCF7/LCC9: an antiestrogen-resistant MCF-7 variant in which acquired resistance to the steroidal antiestrogen ICI 182,780 confers an early cross-resistance to the non-steroidal antiestrogen tamoxifen. Cancer Res 57: 3486-3493, 1997.

9. Lykkesfeldt AE, Larsen SS and Briand P: Human breast cancer cell lines resistant to pure anti-estrogens are sensitive to tamoxifen treatment. Int J Cancer 61: 529-534, 1995.

10. McClelland RA, Barrow D, Madden TA, Dutkowski CM, Pamment J, Knowlden JM, Gee JM and Nicholson RI: Enhanced epidermal growth factor receptor signaling in MCF7 breast cancer cells after long-term culture in the presence of the pure antiestrogen ICI 182,780 (Faslodex). Endocrinology 142: 2776-2788, 2001.

11. Sommer A, Hoffmann J, Lichtner RB, Schneider MR and Parczyk K: Studies on the development of resistance to the pure antiestrogen Faslodex in three human breast cancer cell lines. J Steroid Biochem Mol Biol 85: 33-47, 2003.

12. Rabindran SK, Ross DD, Doyle LA, Yang W and Greenberger LM: Fumitremorgin $C$ reverses multidrug resistance in cells transfected with the breast cancer resistance protein. Cancer Res 60: 47-50, 2000. 
13. Pink JJ and Jordan VC: Models of estrogen receptor regulation by estrogens and antiestrogens in breast cancer cell lines. Cancer Res 56: 2321-2330, 1996.

14. Catherino WH and Jordan VC: Increasing the number of tandem estrogen response elements increases the estrogenic activity of a tamoxifen analogue. Cancer Lett 92: 39-47, 1995.

15. Liu H, Lee ES, Gajdos C, Pearce ST, Chen B, Osipo C, Loweth J, McKian K, De Los Reyes A, Wing L and Jordan VC: Apoptotic action of 17 beta-estradiol in raloxifene-resistant MCF-7 cells in vitro and in vivo. J Natl Cancer Inst 95: 1586-1597, 2003.

16. Dardes RC, Schafer JM, Pearce ST, Osipo C, Chen B and Jordan VC: Regulation of estrogen target genes and growth by selective estrogen-receptor modulators in endometrial cancer cells. Gynecol Oncol 85: 498-506, 2002.

17. Sainsbury JR, Farndon JR, Sherbet GV and Harris AL: Epidermalgrowth-factor receptors and oestrogen receptors in human breast cancer. Lancet i: 364-366, 1985

18. Davidson NE, Gelmann EP, Lippman ME and Dickson RB: Epidermal growth factor receptor gene expression in estrogen receptor-positive and negative human breast cancer cell lines. Mol Endocrinol 1: 216-223, 1987.

19. Knowlden JM, Hutcheson IR, Jones HE, Madden T, Gee JM, Harper ME, Barrow D, Wakeling AE and Nicholson RI: Elevated levels of epidermal growth factor receptor/c-erbB2 heterodimers mediate an autocrine growth regulatory pathway in tamoxifen-resistant MCF-7 cells. Endocrinology 144: 1032-1044, 2003

20. De Cremoux P, Tran-Perennou C, Brockdorff B, Boudou E, Brunner N, Magdelenat H and Lykkesfeldt A: Validation of real-time RT-PCR for analysis of human breast cancer cell lines resistant or sensitive to treatment with antiestrogens. Endocr Relat Cancer 10: 409-418, 2003.

21. Arteaga CL: Epidermal growth factor receptor dependence in human tumors: more than just expression? Oncologist 7: 31-39, 2002.

22. Yarden Y and Sliwkowski MX: Untangling the ErbB signalling network. Nat Rev Mol Cell Biol 2: 127-137, 2001.

23. Gottesman MM, Fojo T and Bates SE: Multidrug resistance in cancer: role of ATP-dependent transporters. Nat Rev Cancer 2: 48-58, 2002.

24. Nakamura Y, Oka M, Soda H, Shiozawa K, Yoshikawa M, Itoh A, Ikegami Y, Tsurutani J, Nakatomi K, Kitazaki T, Doi S, Yoshida H and Kohno S: Gefitinib ('Iressa', ZD1839), an epidermal growth factor receptor tyrosine kinase inhibitor, reverses breast cancer resistance protein/ABCG2-mediated drug resistance. Cancer Res 65: 1541-1546, 2005.

25. Yanase K, Tsukahara S, Asada S, Ishikawa E, Imai $Y$ and Sugimoto Y: Gefitinib reverses breast cancer resistance proteinmediated drug resistance. Mol Cancer Ther 3: 1119-1125 2004.

26. Elkind NB, Szentpetery Z, Apati A, Ozvegy-Laczka C, Varady G, Ujhelly O, Szabo K, Homolya L, Varadi A, Buday L, Keri G, Nemet $\mathrm{K}$ and Sarkadi B: Multidrug transporter ABCG2 prevents tumor cell death induced by the epidermal growth factor receptor inhibitor Iressa (ZD1839, Gefitinib). Cancer Res 65: 1770-1777, 2005

27. Gee JM, Harper ME, Hutcheson IR, Madden TA, Barrow D, Knowlden JM, McClelland RA, Jordan N, Wakeling AE and Nicholson RI: The antiepidermal growth factor receptor agent gefitinib (ZD1839/Iressa) improves antihormone response and prevents development of resistance in breast cancer in vitro. Endocrinology 144: 5105-5117, 2003.

28. Kurebayashi J, Okubo S, Yamamoto Y and Sonoo H: Inhibition of HER1 signaling pathway enhances antitumor effect of endocrine therapy in breast cancer. Breast Cancer 11: 38-41, 2004.

29. Wakeling AE, Nicholson RI and Gee JM: Prospects for combining hormonal and non-hormonal growth factor inhibition. Clin Cancer Res 7: S4350-S4355, 2001.

30. Campiglio M, Locatelli A, Olgiati C, Normanno N, Somenzi G, Vigano L, Fumagalli M, Menard S and Gianni L: Inhibition of proliferation and induction of apoptosis in breast cancer cells by the epidermal growth factor receptor (EGFR) tyrosine kinase inhibitor ZD1839 ('Iressa') is independent of EGFR expression level. J Cell Physiol 198: 259-268, 2004.

31. Allen JD and Schinkel AH: Multidrug resistance and pharmacological protection mediated by the breast cancer resistance protein (BCRP/ABCG2). Mol Cancer Ther 1: 427-434, 2002.

32. Ejendal KF and Hrycyna CA: Multidrug resistance and cancer: the role of the human ABC transporter ABCG2. Curr Protein Pept Sci 3: 503-511, 2002.
33. Han B and Zhang JT: Multidrug resistance in cancer chemotherapy and xenobiotic protection mediated by the half ATPbinding cassette transporter ABCG2. Curr Med Chem Anticancer Agents 4: 31-42, 2004.

34. Doyle LA and Ross DD: Multidrug resistance mediated by the breast cancer resistance protein BCRP (ABCG2). Oncogene 22: 7340-7358, 2003.

35. Ee PL, Kamalakaran S, Tonetti D, He X, Ross DD and Beck WT Identification of a novel estrogen response element in the breast cancer resistance protein (ABCG2) gene. Cancer Res 64: 1247-1251, 2004

36. Imai Y, Ishikawa E, Asada S and Sugimoto Y: Estrogen-mediated post transcriptional down-regulation of breast cancer resistance protein/ABCG2. Cancer Res 65: 596-604, 2005.

37. Rabindran SK, He H, Singh M, Brown E, Collins KI, Annable T and Greenberger LM: Reversal of a novel multidrug resistance mechanism in human colon carcinoma cells by fumitremorgin $\mathrm{C}$. Cancer Res 58: 5850-5858, 1998.

38. Ferrer A, Marce S, Bellosillo B, Villamor N, Bosch F, LopezGuillermo A, Espinet B, Sole F, Montserrat E, Campo E and Colomer D: Activation of mitochondrial apoptotic pathway in mantle cell lymphoma: high sensitivity to mitoxantrone in cases with functional DNA-damage response genes. Oncogene 23 : 8941-8949, 2004.

39. Bhalla K, Ibrado A, Tourkina E, Tang C, Grant S, Bullock G, Huang Y, Ponnathpur V and Mahoney M: High-dose mitoxantrone induces programmed cell death or apoptosis in human myeloid leukemia cells. Blood 82: 3133-3140, 1993.

40. Huisman MT, Chhatta AA, van Tellingen O, Beijnen JH and Schinkel AH: MRP2 (ABCC2) transports taxanes and confers paclitaxel resistance and both processes are stimulated by probenecid. Int J Cancer, 2005

41. Pegram MD, Konecny GE, O'Callaghan C, Beryt M, Pietras R and Slamon DJ: Rational combinations of trastuzumab with chemotherapeutic drugs used in the treatment of breast cancer. J Natl Cancer Inst 96: 739-749, 2004.

42. Slamon DJ, Leyland-Jones B, Shak S, Fuchs H, Paton V, Bajamonde A, Fleming T, Eiermann W, Wolter J, Pegram M, Baselga $\mathrm{J}$ and Norton L: Use of chemotherapy plus a monoclonal antibody against HER2 for metastatic breast cancer that overexpresses HER2. N Engl J Med 344: 783-792, 2001.

43. Marty M, Cognetti F, Maraninchi D, Snyder R, Mauriac L, Tubiana-Hulin M, Chan S, Grimes D, Anton A, Lluch A, Kennedy J, O'Byrne K, Conte P, Green M, Ward C, Mayne K and Extra J-M: Efficacy and safety of trastuzumab combined with docetaxel in patients with human epidermal growth factor receptor 2-positive metastatic breast cancer administered as first-line treatment: results of a randomized phase II trial by the M77001 Study Group. J Clin Oncol: JCO.2005.2004.2173, 2005.

44. Sirotnak FM, Zakowski MF, Miller VA, Scher HI and Kris MG: Efficacy of cytotoxic agents against human tumor xenografts is markedly enhanced by coadministration of ZD1839 (Iressa), an inhibitor of EGFR tyrosine kinase. Clin Cancer Res 6: 4885-4892, 2000.

45. Giaccone G, Herbst RS, Manegold C, Scagliotti G, Rosell R, Miller V, Natale RB, Schiller JH, von Pawel J, Pluzanska A, Gatzemeier U, Grous J, Ochs JS, Averbuch SD, Wolf MK, Rennie P, Fandi A and Johnson DH: Gefitinib in combination with gemcitabine and cisplatin in advanced non-small-cell lung cancer: a phase III trial-INTACT 1. J Clin Oncol 22: 777-784, 2004

46. Herbst RS, Giaccone G, Schiller JH, Natale RB, Miller V, Manegold C, Scagliotti G, Rosell R, Oliff I, Reeves JA, Wolf MK, Krebs AD, Averbuch SD, Ochs JS, Grous J, Fandi A and Johnson DH: Gefitinib in combination with paclitaxel and carboplatin in advanced non-small-cell lung cancer: a phase III trial-INTACT 2. J Clin Oncol 22: 785-794, 2004.

47. Stewart CF, Leggas M, Schuetz JD, Panetta JC, Cheshire PJ, Peterson J, Daw N, Jenkins JJ III, Gilbertson R, Germain GS, Harwood FC and Houghton PJ: Gefitinib enhances the antitumor activity and oral bioavailability of Irinotecan in mice. Cancer Res 64: 7491-7499, 2004.

48. Erlichman C, Boerner SA, Hallgren CG, Spieker R, Wang X-Y, James CD, Scheffer GL, Maliepaard M, Ross DD, Bible KC and Kaufmann SH: The HER tyrosine kinase inhibitor CI1033 enhances cytotoxicity of 7-Ethyl-10-hydroxycamptothecin and topotecan by inhibiting breast cancer resistance protein-mediated drug efflux. Cancer Res 61: 739-748, 2001 
49. Houghton PJ, Germain GS, Harwood FC, Schuetz JD, Stewart CF, Buchdunger $\mathrm{E}$ and Traxler $\mathrm{P}$ : Imatinib mesylate is a potent inhibitor of the ABCG2 (BCRP) transporter and reverses resistance to topotecan and SN-38 in vitro. Cancer Res 64: 2333-2337, 2004.

50. Ozvegy-Laczka C, Hegedus T, Varady G, Ujhelly O, Schuetz JD, Varadi A, Keri G, Orfi L, Nemet K and Sarkadi B: High-affinity interaction of tyrosine kinase inhibitors with the ABCG2 multidrug transporter. Mol Pharmacol 65: 1485-1495, 2004.
51. Wakeling AE, Guy SP, Woodburn JR, Ashton SE, Curry BJ, Barker AJ and Gibson KH: ZD1839 (Iressa): an orally active ihibitor of epidermal growth factor signaling with potential for cancer therapy. Cancer Res 62: 5749-5754, 2002.

52. Brehmer D, Greff Z, Godl K, Blencke S, Kurtenbach A, Weber M, Muller S, Klebl B, Cotten M, Keri G, Wissing J and Daub H: Cellular targets of Gefitinib. Cancer Res 65: 379-382, 2005. 